\title{
A new microwave spectrometer for ground-based observations of water vapour
}

\author{
K. Hallgren ${ }^{1, *}$, P. Hartogh ${ }^{1}$, and C. Jarchow ${ }^{1}$ \\ ${ }^{1}$ Max-Planck-Institut für Sonnensystemforschung, Katlenburg-Lindau, Germany \\ now at: Swedish Defence Research Agency, Stockholm, Sweden
}

Received: 7 May 2013 - Accepted: 8 May 2013 - Published: 27 May 2013

Correspondence to: K. Hallgren (kristofer.hallgren@foi.se)

Published by Copernicus Publications on behalf of the European Geosciences Union.

A ground-based microwave spectrometer

K. Hallgren et al.

\section{Title Page}

\section{Full Screen / Esc}

Printer-friendly Version

Interactive Discussion 


\section{Abstract}

We have developed a new, high time-resolution, microwave heterodyne spectrometer for observations of water vapour in the middle atmosphere. It measures the rotational transition of water vapour at $22.235 \mathrm{GHz}$ in the vertical and horizontal polarisation. The 5 two polarisations are averaged in order to optimise the signal-to-noise ratio. The different polarisations have separate, but identical, signal chains consisting of a $22 \mathrm{GHz}$ cooled HEMT amplifier, a second, warm, $22 \mathrm{GHz}$ HEMT booster amplifier, an IF stage and a Chirp Transform Spectrometer (CTS) backend. Continuous calibration with two internal loads kept at temperatures close to the observed atmosphere, a wobbling opti-

ensures a time resolution of an order of magnitude better than what has been achieved by earlier instruments. The error sources in the retrieved spectrum are discussed and the data is compared and validated against EOS-MLS on the NASA Aura satellite. The profiles are found to be in good agreement with each other.

\section{Introduction}

Ground-based millimetre-wave remote sensing has matured into a powerful tool used in aeronomy and meteorology as well as astronomy. Both active (e.g. radar) and passive (e.g. radiometer) techniques exist and complement each other well. Here we will describe a passive ground-based instrument developed for observations of Earth's atmosphere. Several different atmospheric gases such as ozone, carbon monoxide and water vapour have been detected and are observed on a regular basis with passive ground-based radiometers (Goldsmith et al., 1979; Nedoluha et al., 1996; Hartogh and Jarchow, 1995a,b; Hartogh et al., 2010; Hallgren and Hartogh, 2012; Hallgren et al., 2012). Ground-based observations are carried out on locations around the world and their results have been validated in numerous intercomparison campaigns, between both the ground-based instruments as well as their space-borne counterparts (Feist

AMTD

6, 4677-4703, 2013

A ground-based microwave spectrometer

K. Hallgren et al.

\section{Title Page}

Abstract

\section{Full Screen / Esc}

Printer-friendly Version

Interactive Discussion 
et al., 2000; Nedoluha et al., 2007; Haefele et al., 2009; Straub et al., 2011). The instrument described in this paper is a highly sensitive microwave heterodyne spectrometer observing water vapour in the middle atmosphere. Although there exist a number of transitions in the microwave region for the water molecule only two are useful for 5 ground-based spectroscopy; a relatively weak line at $22.235 \mathrm{GHz}$ and a much stronger line at 183.31 GHz (Hartogh et al., 1991; Pardo et al., 1996; Siegenthaler et al., 2001). Due to the high opacity of the $183.31 \mathrm{GHz}$ line it is less suitable for instruments located at sea level, thus the weaker but optically thinner line at $22.235 \mathrm{GHz}$ is used for this instrument. It is possible to deduce the vertical distribution of the observed specie 10 from the measured line shape which is determined by several molecular parameters. The number of molecules along the line of sight, broadening of the line by collisions (pressure broadening) and the velocity distribution of the molecules (Doppler broadening) are the most important. Above a certain altitude the Doppler broadening exceeds the pressure broadening and although it is possible to get a total column depth of the 15 molecule it is no longer possible to retrieve the vertical distribution above this threshold altitude. This upper limit is strongly dependent on the frequency of the line. For water vapour at $22.235 \mathrm{GHz}$ the threshold can be found between $80-85 \mathrm{~km}$.

Water vapour is a key element in the Earth atmosphere where it has an important role in the photochemistry as well as the climate. Although we can model the general dynamics of water vapour variability in the middle atmosphere well, the small-scale behaviour is not completely understood. The main source is vertical transport through the tropical tropopause cold trap, releasing about $4-4.5 \mathrm{ppmv}$ of water vapour into the lower stratosphere (Holton et al., 1995). Large scale transport mechanisms such as the Brewer-Dobson circulation and the interhemispheric pole-to-pole circulation thereafter distribute water globally. A second source of water, methane, exist above the tropopause. Its photodissociation in the stratosphere and oxidation by the hydroxyl radical leads to an increase in the amount of water with altitude up to approximately 45-60 km (depending on latitude) where it levels out. With increasing altitude and Solar Lyman- $\alpha$ the water photodissociates and the amount of water starts to decrease

\section{AMTD}

$6,4677-4703,2013$

A ground-based microwave spectrometer

K. Hallgren et al.

\section{Title Page}

Abstract

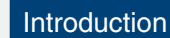

Conclusions

Tables

References

Figures

14

$\Delta$

4

Back

Close 
around $60 \mathrm{~km}$ (Brasseur and Solomon, 1998). A secondary maximum can be found in late summer between $65-75 \mathrm{~km}$ which is caused by autocatalysation of water (Summers et al., 1997; Seele and Hartogh, 1999; Sonnemann et al., 2005). Short term events such as sudden stratospheric warmings are known to inject large amounts of 5 water in the polar regions during winter (Seele and Hartogh, 2000; Manney et al., $2009 a, b)$ but the small scale dynamics are still not well understood. During summer and at high altitude noctilucent clouds are suspected of redistributing the water through freeze-drying of the atmosphere and sublimating the ice-crystals at lower altitudes. Observations confirming this view are however missing (von Zahn and Berger, 2003; von

10 Zahn et al., 2004; Gerding et al., 2007). In the upper mesosphere the amount of water vapour is expected to vary with the atmospheric tides. The tides are global-scale waves which are thermally driven by the periodic absorption of solar radiation throughout the atmosphere. Large-scale latent heat releases by convective systems and non-linear interactions between global-scale waves are also an important excitation source of the tides (Chapman and Lindzen, 1970; Hagan and Forbes, 2002, 2003). Some earlier observations have indicated tidal behaviour of water vapour at mid-latitude locations (Haefele et al., 2009), and an earlier publication of data derived from this instrument describe detections at polar latitudes (Hallgren and Hartogh, 2012).

There is clearly a need for reliable continuous monitoring of mesospheric water 20 vapour as well as high sensitivity observations in order to resolve events on short timescales. In 1995 we installed the microwave spectrometer WASPAM (Wasserdampfund Spurengasmessungen in der Atmosphäre mit Mikrowellen) at ALOMAR, Andøya in northern Norway (Hartogh and Jarchow, 1995b) and in 2008 this instrument was followed by a new, more sensitive instrument called cWASPAM (cooled WASPAM). With cWASPAM the long dataset from WASPAM (Hallgren et al., 2012) is continued and its increased sensitivity will allow us to resolve dynamics on a shorter time-scale than before (Stevens et al., 2003, 2012).
AMTD

$6,4677-4703,2013$

A ground-based microwave spectrometer

K. Hallgren et al.

Title Page

Abstract

Conclusions

Tables

References

Figures

14

$\rightarrow$ I

4

Back

Full Screen / Esc

Printer-friendly Version

Interactive Discussion 


\section{Instrument description}

In order to determine the distribution and short term variability of water vapour at high altitudes a very stable and sensitive instrument is needed. cWASPAM, the instrument presented here, is able to provide these capabilities. A few, almost identical, instru5 ments has been built and installed at observation sites around Europe. cWASPAM1 is located at the ALOMAR site in northern Norway, cWASPAM3 is located at Schneefernerhaus on Zugspitze in Germany and MISI (operated by IAP Kühlungsborn) is located at IAP Kühlungsborn.

The new system is based on the same principles as WASPAM. The increased sensitivity is achieved by additional cooling of the horn antenna and observation of the statistically independent signals of the vertical and horizontal polarisation. A schematic operating principle of cWASPAM can be seen in Fig. 1. The beam falling onto the antenna is alternated between the observed atmosphere and two fixed mirrors, pointing at the calibration loads by means of a rotating mirror. The rotating mirror is a light-weight fixed mirrors are made out of aluminium. The mirrors are all mounted on an optical bench which is moved back in forth in synchronisation with the rotation of the mirror. A photo of cWASPAM1 after installation at the ALOMAR site can be seen in Fig. 2.

The main part of the receiver; the horn antenna, the OMT (ortho-mode transducer), two InP (Indium Phosphite) HEMT (high electron mobility transistor) amplifiers, and the internal calibration loads are mounted in a cooled dewar, whose interior can be seen in Fig. 3. The dewar itself is placed with the optical table on an aluminium structure. The antenna, which has a half-power beamwidth of $3.53^{\circ}$, and the pre-amplifiers are cooled to approximately $15 \mathrm{~K}$, whereas the loads (cold and hot) are kept at higher temperatures; $\approx 45 \mathrm{~K}$ and $\approx 120 \mathrm{~K}$ respectively. At this temperature the noise temperature of the HEMT-amplifiers is approximately $15 \mathrm{~K}$. A commercially available closed-loop helium compressor provides the cooling power in two stages, the first stage delivers $35 \mathrm{~W}$ at $45 \mathrm{~K}$ for the calibration loads and the second stage $6.3 \mathrm{~W}$ at $10 \mathrm{~K}$ for the antenna
AMTD

6, 4677-4703, 2013

A ground-based microwave spectrometer

K. Hallgren et al.

\section{Title Page}

Abstract

\section{Full Screen / Esc}

Printer-friendly Version

Interactive Discussion 
and amplifiers. Outside the dewar another set of amplifiers are mounted which boost the signal a second time before down-conversion to $1.35 \mathrm{GHz}$. The LO has a frequency of $20.885 \mathrm{GHz}$. We use the upper sideband and the lower sideband is suppressed by $>45 \mathrm{~dB}$ using a sideband filter following the amplifier. The setup achieves a receiver 5 temperature of the system of $30 \mathrm{~K}$ for each polarisation (single side-band). Table 1 shows the instrument parameters in a tabulated form.

cWASPAM uses two Chirp Transform Spectrometers (CTS) (Hartogh and Hartmann, 1990; Hartogh and Osterschek, 1995; Villanueva and Hartogh, 2004; Villanueva et al., 2006; Paganini and Hartogh, 2009) as backends, one for each polarisation. The backends are identical and have a bandwidth of $40 \mathrm{MHz}$. In order to be able to resolve the water vapour distribution at high altitude both spectrometers have a high spectral resolution. The width of each channel is $14 \mathrm{kHz}$, but we employ a slight oversampling with the resulting channel spacing of $9.8 \mathrm{kHz}$. For water vapour at $22.235 \mathrm{GHz}$ the Doppler broadening is approximately $30 \mathrm{kHz}$ in Earth's atmosphere, thus we are able to resolve 15 the line at all altitudes to the pressure-Doppler threshold.

Communication between the CTSs and the process control computer, memory handling and the external Ethernet interface of the CTSs are handled by an embedded computer (a PC104). The CTSs and the process-control computer are mounted into a separate $19^{\prime \prime}$ rack, together with a monitoring device that reads the temperature sensors on the calibration loads and a network router for the instrument network.

\section{Instrument control and monitoring}

The process-control and house-keeping of the instrument is controlled by an ordinary desktop PC running a real-time patched Linux system. It controls the normal operation of the instrument, monitors system parameters and acts as a first buffer for storing the data before archiving at the MPS. Accurate and real-time temperature measurements of the loads needed for correct calibration of the data are provided by cryogenic silicon diodes mounted directly at the back of each calibration load. We also collect
AMTD

$6,4677-4703,2013$

A ground-based microwave spectrometer

K. Hallgren et al.

\section{Title Page}

Abstract Introduction

Conclusions

Tables

References

Figures

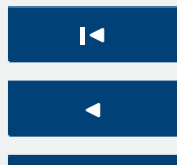

$\rightarrow 1$

Back

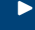

Close

\section{Full Screen / Esc}

Printer-friendly Version

Interactive Discussion 
temperatures of the amplifiers, dispersive delay filters in the spectrometers and ambient room temperature.

The software control of the instrument was written with a modular approach which adds flexibility and facilitates debugging. In order to achieve a deterministic behaviour 5 of the process control the computer has been patched with a Real-Time Application Interface (RTAI). It provides latencies of the system of approximately $15 \mu \mathrm{s}$, which is much faster than the time needed to rotate the mirrors $(\approx 300 \mathrm{~ms})$. The control of the system can therefore be assumed to be instantaneous. The measurement process itself is run as an infinite loop in an overhead script which sends instructions to each 10 standalone process, one for each step in the measurement cycle. Certain processes are run in parallel such as the movement of the optical table and integration in the CTS which demands exact timing in the interprocess communication. By keeping each measurement exactly synchronised with the wobbler movement and fine-tuning the speed and length to $n \cdot \lambda / 2$ we can minimise standing waves in the optical path similar to the technique discussed in Gustincic (1977). Furthermore, by making sure the process control is well defined in time the "dead-time" between each step in the measurement cycle is removed.

The communication between the process-control computer and the separate units of the instrument is done over an instrument-wide LAN, enabling remote control of almost all aspects of the instrument. This network is also used for the raw data and monitorlogs. For mirror rotation and wobbling of the optical table the parallel ports are used as they demand a minimal amount of overhead code.

One development goal of the instrument was low maintenance requirements, thus a high degree of automation has been implemented. All monitored parameters are continuously controlled and if anomalous values are encountered or if a process is stopped a warning email is sent to the operator(s). The retrieved data are saved in a raw, binary, format together with system performance parameters to allow maximum flexibility in the analysis. The total amount of data is approximately 500 MBytes every $24 \mathrm{~h}$. In order to increase data safety the hard-drives on the process-control computer
AMTD

$6,4677-4703,2013$

A ground-based microwave spectrometer

K. Hallgren et al.

\section{Title Page}

Abstract

\section{Full Screen / Esc}

Printer-friendly Version

Interactive Discussion 
are mirrored with a soft RAID1 array which has the capacity to store up to 50 days of autonomous observations in case the daily backup and archiving process fails.

Calibration of the instrument deals with two separate parameters; an offset power (commonly denoted as $T_{r}$ ) which is generated within the system (uncoupled to the 5 observed region) and the gain coefficient $(\Lambda)$ in the system. Assuming that the system has a linear amplification in the measured range the gain coefficient and offset power can be calculated by comparing the power output of two calibration loads at well known temperatures to the output power from the observed region. During normal operation the two loads are used in a hot-cold, interleaved, calibration scheme in which

lowing atmospheric spectrum. The load temperatures are kept close to the expected atmospheric temperature range in order to reduce second order non-linearities and the effective noise temperature (Jarchow, 1998; Paganini and Hartogh, 2009). In addition, a small offset between the measured physical temperature of the calibration loads and their radiated temperature needs to be accounted for. By doing an initial calibration with liquid nitrogen and a microwave absorber at room temperature this offset can be calculated and included into the calibration.

\section{Retrieval}

We use a retrieval pipeline which was originally developed for WASPAM but upgraded 20 backends is averaged. As the underlying polarisations are orthogonal the retrieved spectra are uncorrelated and averaging of the spectra will reduce the noise with a factor of $\frac{1}{\sqrt{2}}$. In detail, and by assigning $\left(x_{1}\right.$ and $\left.x_{2}\right)$ to each spectrometer:

$\widehat{x}=\left(\frac{1}{\sigma_{1}^{2}}+\frac{1}{\sigma_{2}^{2}}\right)^{-1}\left(\frac{x_{1}}{\sigma_{1}^{2}}+\frac{x_{2}}{\sigma_{2}^{2}}\right)$,

AMTD

$6,4677-4703,2013$

A ground-based microwave spectrometer

K. Hallgren et al.

\section{Title Page}

Abstract

\section{Full Screen / Esc}

Printer-friendly Version

Interactive Discussion 
where $\hat{x}$ is the estimate of the combined measurements. The variance of each spectrometer $\left(\sigma_{i}\right)$ is used as weight in the calculation and the averaging takes into account the signal-to-noise ratio (SNR) of each polarisation. The higher the SNR the higher the weight. The new variance, and thus the noise of the new signal can be described as

$$
5 \frac{1}{\sigma_{n}}=\frac{1}{\sigma_{1}}+\frac{1}{\sigma_{2}} \text {. }
$$

With $\sigma_{1} \approx \sigma_{2}$ this results in:

$$
\sigma_{n}=\frac{\sigma_{1}}{2}
$$

which is equivalent of dividing the time needed to reach a certain SNR by two, essentially doubling the time-resolution.

10 To remove residual standing waves in the spectra we use a general approach which involve using the harmonics of the spectrometer bandwidth according to the Lomb periodogram method (Lomb, 1976). The last step in the retrieval is the actual inversion of the spectral line to produce a vertical profile. We use the optimal estimation method (OEM), first described in Rodgers (1976). The atmospheric data needed to calculate 15 the line broadening are reanalysis-data taken from NCEP (McPherson et al., 1979) up to $0.4 \mathrm{mb}$ nudged to a CIRA86 climatology (Fleming et al., 1990). At ALOMAR the CIRA86 background is corrected by the climatology from Lübken (1999). Information about the spectral parameters are taken from the JPL catalogue (Pickett et al., 1998). We use a piecewise linear a priori profile which is kept unchanged during the course of the year to facilitate intercomparison between seasons. An example of a typical retrieved line after only $4 \mathrm{~h}$ of integration time with residual noise and calculated vertical distribution can be seen in Fig. 4 with the corresponding averaging kernels in Fig. 5. The averaging kernels represent the sensitivity of the instrument at any given level to the above and below situated layers and the a priori profile. Mathematically it is 25 a square matrix, $\overline{\mathbf{A}}$, where each row corresponds to a level in the model atmosphere and the relation to the other levels.

\section{AMTD}

6, 4677-4703, 2013

A ground-based microwave spectrometer

K. Hallgren et al.

\section{Title Page}

Abstract

\section{Full Screen / Esc}

Printer-friendly Version

Interactive Discussion 


\section{Validation of the data}

During winter 2009 cWASPAM3 was involved in ARIS (Alpine Radiometer Intercomparison at the Schneefernerhaus), an intercomparison campaign at the research station Schneefernerhaus on Zugspitze $\left(47.25^{\circ} \mathrm{N}\right.$ and $10.58^{\circ} \mathrm{E}$ ) in Germany (Straub et al., 5 2011). Three ground-based heterodyne microwave spectrometers participated in the campaign. All spectrometers observed water vapour at $22.235 \mathrm{GHz}$ and pointed in the same direction but used different receivers, spectrometers and calibration techniques. The general conclusion of the campaign was that despite the differences they all agreed within the error bars on the water vapour distribution. In addition to the ground-based intercomparison the retrieved profiles were also compared to water vapour profiles from EOS-MLS (Waters et al., 2006). During the campaign approximately 70 collocated spectra between cWASPAM3 and EOS-MLS were collected. The spectra from EOS-MLS are however dispersed over a larger area due to orbital restrictions and the ones used in the intercomparison are constrained to $\pm 1^{\circ}$ in latitude and $\pm 5^{\circ}$ in longitude compared to the cWASPAM3 observations. cWASPAM3 is pointing southwards $\left(177^{\circ}\right)$ with an elevation angle of $15^{\circ}$ and the atmosphere observed is therefore a region between 180-320 km south of Zugspitze. The collocation parameters were therefore centred at $45^{\circ} \mathrm{N}, \approx 250 \mathrm{~km}$ to the south. The profiles from EOS-MLS can be assumed to be instantaneous compared to the ones from cWASPAM. In order to account for the differences in sensitivity and vertical resolution between cWASPAM and EOS-MLS the profiles from EOS-MLS are convolved with the averaging kernels from cWASPAM3. By doing so the vertical resolution, and sensitivity at high altitude of EOS-MLS is reduced to that of cWASPAM3. Thus, at the altitudes where the sensitivity of cWASPAM3 decreases and most information is taken from the a priori, the profiles from EOS-MLS will 25 be influenced in a similar way by the a priori. The new profiles are calculated according to

$\widehat{\bar{x}}=(1-\overline{\mathbf{A}}) \bar{x}_{0}+\overline{A x}$.
AMTD

$6,4677-4703,2013$

A ground-based microwave spectrometer

K. Hallgren et al.

\section{Title Page}

Abstract

\section{Full Screen / Esc}

Printer-friendly Version

Interactive Discussion 
The error, $\overline{D \epsilon}$, of the EOS-MLS profile is unknown and contained in the $\bar{x}$ term and the a priori, $\overline{x_{0}}$, is the same for both instruments. We compared the data-set from EOS-MLS with to different integration times for cWASPAM, 12 and $4 \mathrm{~h}$. Results from the comparison can be seen in Fig. 7. The difference was calculated relative to the 5 EOS-MLS measurements according to,

$\bar{d}=\frac{\bar{x}_{\mathrm{CWASPAM}}-\bar{x}_{\text {EOS-MLS }} .}{\bar{x}_{\text {EOS-MLS }}}$

As expected when the EOS-MLS profiles are convolved with the averaging kernels from cWASPAM3 there is no difference at low altitude were the kernels are zero and all information is taken from the a priori. At the uppermost altitudes cWASPAM is less senfrom the measurement, and not only from the a priori. Although both EOS-MLS and cWASPAM3 are weighted similarly between measurement and a priori the measurements from EOS-MLS are much less noisy. The comparison at this level will therefore be less consistent as the cWASPAM3 profile has a relatively large portion of noise and will not reflect the actual atmosphere as well compared to the lower layers. EOS-MLS overestimates the amount of water vapour compared to cWASPAM3 in two distinct regions, between 45 and $55 \mathrm{~km}$, and from $65 \mathrm{~km}$ and upward. The variability of the difference between the instruments is larger at high altitude $(>70 \mathrm{~km})$ than in the mid to low part of the profile. One specific occasion show a much larger error then the others. On 20 February the discrepancy was $\approx 100 \%$ between the measured amount of water vapour above $75 \mathrm{~km}$ between cWASPAM3 and EOS-MLS. The sky brightness temperature of the day was less than $100 \mathrm{~K}$, meaning that observations were feasible. At the same time all the instrument parameters were normal. Interestingly the difference between the profile from the long integration $(12 \mathrm{~h})$ is twice as big as the one for the short integration $(4 \mathrm{~h})$. We interpret this as a short term decrease in the water vapour during the time of the EOS-MLS overpass. A sharp, short term, dip in the volume mixing ratio would be smoothed out by our $12 \mathrm{~h}$ integration time, but less so in retrievals with 4687

\section{AMTD}

$6,4677-4703,2013$

A ground-based microwave spectrometer

K. Hallgren et al.

\section{Title Page}

Abstract

Conclusions

Tables

References

Figures

14

$\Delta$

4

Back

Full Screen / Esc

Printer-friendly Version

Interactive Discussion
$>$

Close

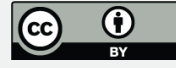


a shorter integration time. This could imply that the amount of water vapour at these altitudes is relatively variable on short time-scales. For the mid to lower part of the retrieval, where the signal is already good for the $4 \mathrm{~h}$ integration time, no appreciable difference can be seen between the $12 \mathrm{~h}$ integration compared to the $4 \mathrm{~h}$ integration.

\section{Error analysis}

The end product, a vertical distribution of water vapour is affected by many different sources; internal and instrumental as well as uncertainties in the information about the state of the atmosphere and parameters of the observed line. The total error, or uncertainty, of the retrieved profile, can be seen as a function of altitude in Fig. 6 . By changing 10 each parameter in the inversion and calculating the difference of the retrieved profile after the parameter change to the original profile for a $24 \mathrm{~h}$ integration time the impact of each parameter can be explored. We have chosen a long integration time to isolate systematic errors from stochastic errors. In general there are no significant differences between the errors at different integration times. Some of the parameters in the for15 ward model are empirically measured which introduce errors in the final profile. For example, uncertainties in the determination of the tropospheric transmission introduce errors on the order of $1 \%$ in the profile. The error attributed to the temperature used in the retrieval are calculated by changing temperature in the forward model by $\pm 5 \mathrm{~K}$, these issues are investigated in more detail in Jarchow (1998) and Hallgren (2010). 20 The spectroscopy error (green line) in Fig. 6 contains errors caused by uncertainties in the pressure broadening constant and the line intensity. These parameters have been calculated and compared to measured levels and shown to be very precise, with the systematic uncertainties similar to the stochastic errors (Payne et al., 2008; Tretyakov et al., 2008). The error displayed here is derived by using an uncertainty in the pressure broadening constant of $3.5 \%$ and the line intensity of $0.5 \%$. Errors related to transmission losses in the windows are investigated in detail in Jarchow (1998) and found to be negligible. Currently we cannot determine the elevation angle with a better precision
AMTD

$6,4677-4703,2013$

A ground-based microwave spectrometer

K. Hallgren et al.

\section{Title Page}

Abstract

\section{Full Screen / Esc}

Printer-friendly Version

Interactive Discussion 
than $\pm 0.5^{\circ}$ which introduce an uncertainty in the optical pathlength actually observed. The corresponding error as shown in Fig. 6 is the result of varying the elevation angle in the forward model by $\pm 0.5^{\circ}$. The error is calculated for cWASPAM 1 which has an elevation angle of $18^{\circ}$. The channel width of the CTS might introduce an error in the 5 inversion process due to the sampling of the line. If the channel width is denoted $v_{\mathrm{ch}}$ the line centre can vary with $\pm \frac{v_{c h}}{2}$ and still be measured within the centre channel. Due to pressure broadening this error is only noticeable at altitudes above $70 \mathrm{~km}$. However, if the hyperfine structure of the water vapour spectrum is not taken into account the error is visible already at $50 \mathrm{~km}$ and above $70 \mathrm{~km}$ the error is larger than $10 \%$.

10 According to OEM the stochastic noise, $\epsilon_{y}$, in each measured spectra is represented as the measurement noise error. As can be seen in Fig. 6 the error associated with the measurement noise is approximately $5 \%$ up to $70 \mathrm{~km}$ and above that it increases rapidly. This is the single largest error component. It is however important to note that better observation conditions, which reduce the stochastic noise, do not reduce the 15 measurement noise error in a linear manner. Instead the averaging kernels will be improved resulting in a better vertical resolution. The OEM tries to find the optimal weighting between a noisy measurement and the a priori profile. As long as the estimated error of the a priori profile is unchanged the optimal weighting will be the same, hence the averaging kernels change with varying observational conditions and instru-

ment sensitivity. In some cases were a minimal noise is to be preferred over a better vertical resolution it might be of interest to use the Backus-Gilbert retrieval method instead of the OEM (Backus and Gilbert, 1970; Jarchow and Hartogh, 1995, 1998).

\section{Conclusions}

A new, highly sensitive, heterodyne microwave spectrometer has been described. 25 Compared with the WASPAM instrument a substantial improvement in the sensitivity was achieved by cooling of the horn antenna and the measurement of two polarisations. As a result the time resolution in the upper mesosphere went from 24 to $4 \mathrm{~h}$.
AMTD

$6,4677-4703,2013$

A ground-based microwave spectrometer

K. Hallgren et al.

\section{Title Page}

Abstract

Conclusions

Tables

References

Figures

14

$\Delta$

4

Back

Full Screen / Esc

Printer-friendly Version

Interactive Discussion
$>$

Close

\section{active Discussion}

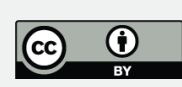


Validation of the instrument, against two other water vapour heterodyne spectrometers during a ground-based campaign at the Schneefernerhaus near Zugspitze showed a good agreement. Comparison with satellite data from EOS-MLS showed a slight systematic underestimation of cWASPAM3. Despite the fact that a multitude of param5 eters with different uncertainties are used in the retrieval the single most important component of the error profile is the measurement noise. Furthermore, decreasing the uncertainty in many of the parameters used will only marginally improve the measurement.

Acknowledgements. This work was supported by the German Research Community DFG, 10 grant HA-3261/7-1. The authors would like to thank the staff at ALOMAR and UFS for their support in administering the instruments. We are also greatly thankful for the work done by the Atmospheric and Dynamics branch at NASA Goddard Space Center in producing and making the NCEP data available through their automailer system.

15 The service charges for this open access publication have been covered by the Max Planck Society.

\section{References}

Backus, G. and Gilbert, F.: Uniqueness in the inversion of inaccurate gross Earth data, Philos. T. Roy. Soc. S.-A, 266, 123-192, 1970. 4689

Brasseur, G. and Solomon, S.: Aeronomy of the middle atmosphere, D. Reidel Publishing Company, Dordrecht,, 1998. 4680

Chapman, S. and Lindzen, R.: Atmospheric tides, thermal and gravitational, Reidel, Dordrecht, 1970. 4680

Feist, D. G., Aellig, C. P., Solomon, P. M., Barrett, J. W., Zoonematkermani, S., Harfrom the Millimeter-wave Atmospheric Sounder (MAS), J. Geophys. Res., 105, 9053-9062, doi:10.1029/1999JD901175, 2000. 4678

AMTD

6, 4677-4703, 2013

A ground-based microwave spectrometer

K. Hallgren et al.

\section{Title Page}

Abstract Introduction

Conclusions

References

Tables

Figures

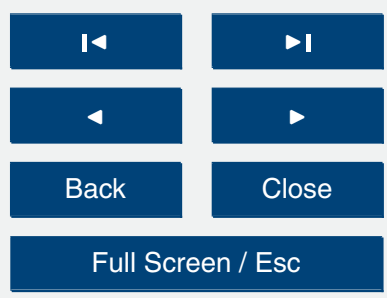

Printer-friendly Version

Interactive Discussion 
Fleming, E. L., Chandra, S., Barnett, J., and Corney, M.: Zonal mean temperature, pressure, zonal wind and geopotential height as functions of latitude, Adv. Space Res., 10, 11-59, doi:10.1016/0273-1177(90)90386-E, 1990. 4685

Gerding, M., Höffner, J., Rauthe, M., Singer, W., Zecha, M., and Lübken, F.-J.: Simultaneous 5 observation of noctilucent clouds, mesospheric summer echoes, and temperature at a midlatitude station ( $\left.54^{\circ} \mathrm{N}\right)$, J. Geophys. Res.-Atmos., 112, D12111, doi:10.1029/2006JD008135, 2007. 4680

Goldsmith, P. F., Litvak, M. M., Plambeck, R. L., and Williams, D. R. W.: Carbon monoxide mixing ratio in the mesosphere derived from ground-based microwave measurements, J. Geophys. Res., 84, 416-418, doi:10.1029/JA084iA02p00416, 1979. 4678

Gustincic, J. J.: A quasi optical receiver system, in: IEEE Conference Proceeding on MTT, San Diego, USA, 99-100, 1977. 4683

Haefele, A., De Wachter, E., Hocke, K., Kämpfer, N., Nedoluha, G. E., Gomez, R. M., Eriksson, P., Forkman, P., Lambert, A., and Schwartz, M. J.: Validation of ground-based microwave radiometers at $22 \mathrm{GHz}$ for stratospheric and mesospheric water vapor, J. Geophys. Res.Atmos., 114, D23305, doi:10.1029/2009JD011997, 2009. 4679, 4680

Hagan, M. E. and Forbes, J. M.: Migrating and nonmigrating diurnal tides in the middle and upper atmosphere excited by tropospheric latent heat release, J. Geophys. Res.-Atmos., 107, 4754, doi:10.1029/2001JD001236, 2002. 4680

Hagan, M. E. and Forbes, J. M.: Migrating and nonmigrating semidiurnal tides in the upper atmosphere excited by tropospheric latent heat release, J. Geophys. Res.-Space, 108, 1062, doi:10.1029/2002JA009466, 2003. 4680

Hallgren, K.: Mesospheric water vapor - variability at different timescales observed by groundbased microwave spectroscopy, Ph. D. thesis, Universität Rostock, 2010. 4688

Hallgren, K. and Hartogh, P.: First detection of tidal behaviour in polar mesospheric water vapour by ground based microwave spectroscopy, Atmos. Chem. Phys., 12, 3753-3759, doi:10.5194/acp-12-3753-2012, 2012. 4678, 4680

Hallgren, K., Hartogh, P., and Jarchow, C.: Climatology of middle atmospheric water vapour above the ALOMAR observatory in northern Norway, Atmos. Chem. Phys. Discuss., 12, 30 31531-31560, doi:10.5194/acpd-12-31531-2012, 2012. 4678, 4680

Hartogh, P. and Hartmann, G. K.: A high-resolution chirp transform spectrometer for microwave measurements, Meas. Sci. Technol., 1, 592-595, 1990. 4682

\section{AMTD}

6, 4677-4703, 2013

A ground-based microwave spectrometer

K. Hallgren et al.

\section{Title Page}

Abstract

Conclusions

References

Tables

Figures

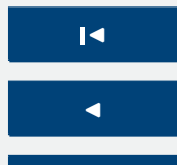

$\rightarrow 1$

Back

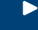

Close

\section{Full Screen / Esc}

Printer-friendly Version

Interactive Discussion 
Hartogh, P. and Jarchow, C.: Groundbased microwave detection of middle atmospheric ozone, in: Global Process Monitoring and Remote Sensing of Ocean and Sea Ice, EUROPTO-Series 2586, SPIE, Bellingham, 206-214, 1995a. 4678

Hartogh, P. and Jarchow, C.: Groundbased detection of middle atmospheric water vapor, in: 5 Global Process Monitoring and Remote Sensing of Ocean and Sea Ice, EUROPTO-Series 2586, SPIE, Bellingham, 188-195, 1995b. 4678, 4680

Hartogh, P. and Osterschek, K.: Multiband chirp transform spectrometer for the microwave remote sensing of middle atmospheric trace gases, in: Society of Photo-Optical Instrumentation Engineers (SPIE) Conference Series, edited by: Fujisada, H. and Sweeting, M. N., vol. 2583 of Presented at the Society of Photo-Optical Instrumentation Engineers (SPIE) Conference, 282-289, 1995. 4682

Hartogh, P., Hartmann, G. K., and Zimmerman, P.: Simultaneous water vapour and ozone measurements with millimeterwaves in the stratosphere and mesosphere, in: IEEE Catalog Number 91CH2971-0, vol. 1, 227-230, 1991. 4679

15 Hartogh, P., Sonnemann, G. R., Grygalashvyly, M., Song, L., Berger, U., and Lübken, F.: Water vapor measurements at ALOMAR over a solar cycle compared with model calculations by LIMA, J. Geophys. Res.-Atmos., 115, D00I17, doi:10.1029/2009JD012364, 2010. 4678

Holton, J. R., Haynes, P. H., Mclntyre, M. E., Douglass, A. R., Rood, R. B., and Pfister, L.: Stratosphere-troposphere exchange, Rev. Geophys., 33, 403-439, doi:10.1029/95RG02097, 1995. 4679

Jarchow, C.: Bestimmung atmosphärischer Wasserdampf- und Ozonprofile mittels bodengebundener Millimeterwellen-Fernerkundung, Ph. D. thesis, Universität Bremen, Bremen, 1998. 4684,4688

Jarchow, C. and Hartogh, P.: Retrieval of data from ground-based microwave sensing of the 25 middle atmosphere: comparison of two inversion techniques, in: Global Process Monitoring and Remote Sensing of Ocean and Sea Ice, EUROPTO-Series 2586, SPIE, Bellingham, 196-205, 1995. 4689

Jarchow, C. and Hartogh, P.: Analysis of forward models using the singular value decomposition algorithm, in: Satellite Remote Sensing of Clouds and the Atmosphere II, edited by:

$30 \quad$ Haigh, J. D., vol. 3220 of Proceedings of SPIE, SPIE, London, 163-173, 1998. 4689

Lomb, N. R.: Least-squares frequency analysis of unequally spaced data, Astrophys. Space Sci., 39, 447-462, doi:10.1007/BF00648343, 1976. 4685

\section{AMTD}

6, 4677-4703, 2013

A ground-based microwave spectrometer

K. Hallgren et al.

\section{Title Page}

Abstract Introduction

Conclusions

Tables

References

Figures

14

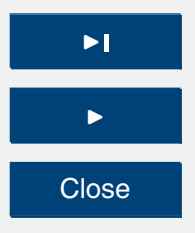

Back

Full Screen / Esc

Printer-friendly Version

Interactive Discussion 
Lübken, F.: Thermal structure of the arctic summer mesosphere, J. Geophys. Res., 104, 91359150, doi:10.1029/1999JD900076, 1999. 4685

Manney, G. L., Harwood, R. S., MacKenzie, I. A., Minschwaner, K., Allen, D. R., Santee, M. L., Walker, K. A., Hegglin, M. I., Lambert, A., Pumphrey, H. C., Bernath, P. F., Boone, C. D.,

$5 \quad$ Schwartz, M. J., Livesey, N. J., Daffer, W. H., and Fuller, R. A.: Satellite observations and modeling of transport in the upper troposphere through the lower mesosphere during the 2006 major stratospheric sudden warming, Atmos. Chem. Phys., 9, 4775-4795, doi:10.5194/acp-9-4775-2009, 2009a. 4680

Manney, G. L., Schwartz, M. J., Krüger, K., Santee, M. L., Pawson, S., Lee, J. N., Daffer, W. H., Fuller, R. A., and Livesey, N. J.: Aura Microwave Limb Sounder observations of dynamics and transport during the record-breaking 2009 Arctic stratospheric major warming, Geophys. Res. Lett., 36, L12815, doi:10.1029/2009GL038586, 2009b. 4680

McPherson, R. D., Bergman, K. H., Kistler, R. E., Rasch, G. E., and Gordon, D. S.: The NMC Operational Global Data Assimilation System, Mon. Weather Rev., 107, 1445-1461, doi:10.1175/1520-0493(1979)107<1445:TNOGDA>2.0.CO;2, 1979. 4685

Nedoluha, G. E., Bevilacqua, R. M., Michael Gomez, R., Waltman, W. B., Hicks, B. C., Thacker, D. L., and Andrew Matthews, W.: Measurements of water vapor in the middle atmosphere and implications for mesospheric transport, J. Geophys. Res., 101, 21183-21194, doi:10.1029/96JD01741, 1996. 4678

20 Nedoluha, G. E., Gomez, R. M., Hicks, B. C., Bevilacqua, R. M., Russell, J. M., Connor, B. J., and Lambert, A.: A comparison of middle atmospheric water vapor as measured by WVMS, EOS-MLS, and HALOE, J. Geophys. Res.-Atmos., 112, D24S39, doi:10.1029/2007JD008757, 2007. 4679

Paganini, L. and Hartogh, P.: Analysis of nonlinear effects in microwave spectrometers, J. Geophys. Res.-Atmos., 114, D13305, doi:10.1029/2008JD011141, 2009. 4682, 4684

Pardo, J. R., Cernicharo, J., Lellouch, E., and Paubert, G.: Ground-based measurements of middle atmospheric water vapor at $183 \mathrm{GHz}$, J. Geophys. Res., 101, 28723, doi:10.1029/96JD02687, 1996. 4679

Payne, V., Delamere, J., Cady-Pereira, K., Gamache, R., Moncet, J.-L., Mlawer, E., and Clough, S.: Air-Broadened Half-Widths of the 22- and 183-GHz Water-Vapor Lines, IEEE T. Geosci. Remote, 46, 3601-3617, doi:10.1109/TGRS.2008.2002435, 2008. 4688
AMTD

6, 4677-4703, 2013

A ground-based microwave spectrometer

K. Hallgren et al.

\section{Title Page}

Abstract

\section{Full Screen / Esc}

Printer-friendly Version

Interactive Discussion

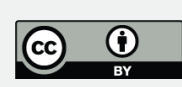


Pickett, H. M., Poynter, I. R. L., Cohen, E. A., Delitsky, M. L., Pearson, J. C., and Muller, H. S. P.: Submillimeter, millimeter and microwave spectral line catalog., J. Quant. Spectrosc. Ra., 60, 883-890, doi:10.1016/S0022-4073(98)00091-0, 1998. 4685

Rodgers, C. D.: Retrieval of atmospheric temperature and composition from remote 5 measurements of thermal radiation, Rev. Geophys. Space Phys., 14, 609-624, doi:10.1029/RG014i004p00609, 1976. 4685

Seele, C. and Hartogh, P.: Water vapor of the polar middle atmosphere: annual variation and summer mesosphere conditions as observed by ground-based microwave spectroscopy, Geophys. Res. Lett., 26, 1517-1520, 1999. 4680

10 Seele, C. and Hartogh, P.: A case study on middle atmospheric water vapor transport during the February 1998 stratospheric warming, Geophys. Res. Lett., 26, 3309-3312, 2000. 4680

Siegenthaler, A., Lezeaux, O., Feist, D., and Kampfer, N.: First water vapor measurements at $183 \mathrm{GHz}$ from the high alpine station Jungfraujoch, IEEE T. Geosci. Remote, 39, 2084-2086, doi:10.1109/36.951108, 2001. 4679

Sonnemann, G. R., Grygalashvyly, M., and Berger, U.: Autocatalytic water vapor production as a source of large mixing ratios within the middle to upper mesosphere, J. Geophys. Res.Atmos., 110, D15303, doi:10.1029/2004JD005593, 2005. 4680

Stevens, M. H., Gumbel, J., Englert, C. R., Grossmann, K. U., Rapp, M., and Hartogh, P.: Polar mesospheric clouds formed from space shuttle exhaust, Geophys. Res. Lett., 30, 1546, doi:10.1029/2003GL017249, 2003. 4680

Stevens, M. H., Lossow, S., Fiedler, J., Baumgarten, G., Lübken, F.-J., Hallgren, K., Hartogh, P., Randall, C. E., Lumpe, J., Bailey, S. M., Niciejewski, R., Meier, R. R., Plane, J. M. C., Kochenash, A. J., Murtagh, D. P., and Englert, C. R.: Bright polar mesospheric clouds formed by main engine exhaust from the space shuttle's final launch, J. Geophys. Res.-Atmos., 117, D19206, doi:10.1029/2012JD017638, 2012. 4680

Straub, C., Murk, A., Kämpfer, N., Golchert, S. H. W., Hochschild, G., Hallgren, K., and Hartogh, P.: ARIS-Campaign: intercomparison of three ground based $22 \mathrm{GHz}$ radiometers for middle atmospheric water vapor at the Zugspitze in winter 2009, Atmos. Meas. Tech., 4, 1979-1994, doi:10.5194/amt-4-1979-2011, 2011. 4679, 4686

30 Summers, M. E., Conway, R. R., Siskind, D. E., Stevens, M. H., Offermann, D., Riese, M., Preusse, P., Strobel, D. F., and Russell III, J. M.: Implications of satellite $\mathrm{OH}$ observations for middle atmospheric $\mathrm{H}_{2} \mathrm{O}$ and ozone, Science, 277, 1967-1970, doi:10.1126/science.277.5334.1967, 1997. 4680

\section{AMTD}

6, 4677-4703, 2013

A ground-based microwave spectrometer

K. Hallgren et al.

\section{Title Page}

Abstract Introduction

Conclusions References

Tables Figures

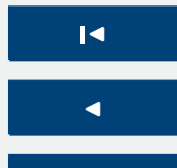
$\rightarrow 1$

\section{Full Screen / Esc}

Printer-friendly Version

Interactive Discussion

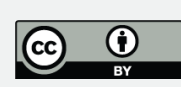


Tretyakov, M., Golubiatnikov, G., Parshin, V., Koshelev, M., and Krupnov, A.: Obtaining precise constants of atmospheric lines in the millimeter and submillimeter wavelength ranges, Radiophys. Quantum El., 51, 713-717, doi:10.1007/s11141-008-9074-y, 2008. 4688

Villanueva, G. and Hartogh, P.: The high resolution chirp transform spectrometer for the sofia5

great instrument, Exp. Astron., 18, 77-91, doi:10.1007/s10686-005-9004-3, 2004. 4682

Villanueva, G., Hartogh, P., and Reindl, L.: A digital dispersive matching network for SAW devices in chirp transform spectrometers, IEEE T. Microwave T. Tech., 54, 1415-1424, doi:10.1109/TMTT.2006.871244, 2006. 4682

von Zahn, U. and Berger, U.: Persistent ice cloud in the midsummer upper mesosphere at high latitudes: three dimensional modeling and cloud interactions with ambient water vapor, J. Geophys Res., 108, 8451, doi:10.1029/2002JD002409, 2003. 4680

von Zahn, U., Baumgarten, G., Berger, U., Fiedler, J., and Hartogh, P.: Noctilucent clouds and the mesospheric water vapour: the past decade, Atmos. Chem. Phys., 4, 2449-2464, doi:10.5194/acp-4-2449-2004, 2004. 4680

15 Waters, J. W., Froidevaux, L., Harwood, R. S., Jarnot, R. F., Pickett, H. M., Read, W. G., Siegel, P. H., Cofield, R. E., Filipiak, M. J., Flower, D. A., Holden, J. R., Lau, G. K., Livesey, N. J., Manney, G. L., Pumphrey, H. C., Santee, M. L., Wu, D. L., Cuddy, D. T., Lay, R. R., Loo, M. S., Perun, V. S., Schwartz, M. J., Stek, P. C., Thurstans, R. P., Boyles, M. A., Chandra, K. M., Chavez, M. C., Chen, G., Chudasama, B. V., Dodge, R., Fuller, R. A., Girard, M. A., Jiang, J. H., Jiang, Y., Knosp, B. W., Labelle, R. C., Lam, J. C., Lee, A. K., Miller, D., Oswald, J. E., Patel, N. C., Pukala, D. M., Quintero, O., Scaff, D. M., Vansnyder, W., Tope, M. C., Wagner, P. A., and Walch, M. J.: The Earth Observing System Microwave Limb Sounder (EOS MLS) on the Aura satellite, IEEE T. Geosci. Remote, 44, 1075-1092, doi:10.1109/TGRS.2006.873771, 2006. 4686
AMTD

6, 4677-4703, 2013

A ground-based microwave spectrometer

K. Hallgren et al.

Title Page

Abstract Introduction

Conclusions

Tables

References

Figures

14

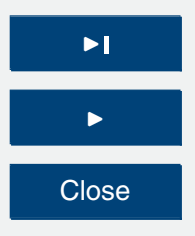

Back

Close

Full Screen / Esc

Printer-friendly Version

Interactive Discussion 
Table 1. Parameter specification for the cWASPAM instruments.

\begin{tabular}{ll}
\hline Optical setup & Cooled horn antenna \\
Antenna beamwidth (HPBW) & $3.53^{\circ}$ \\
\hline Receiver type & Dual polarisation, total power \\
Receiver temperature & $\approx 30 \mathrm{~K}$ \\
Receiver operation mode & Single side band \\
Side-band suppression & $45 \mathrm{~dB}$ \\
Preamplifier & Cooled HEMT \\
\hline Backend type & $\mathrm{CTS}$ \\
Spectral resolution & $9.8 \mathrm{kHz}$ \\
Bandwidth & $40 \mathrm{MHz}$ \\
No of channels & 4096 \\
\hline Calibration & Interleaved hot-cold \\
\hline
\end{tabular}

AMTD

$6,4677-4703,2013$

A ground-based microwave spectrometer

K. Hallgren et al.

Title Page

Abstract

Introduction

Conclusions

References

Tables

Figures

14

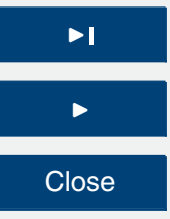

Back

Close

Full Screen / Esc

Printer-friendly Version

Interactive Discussion 


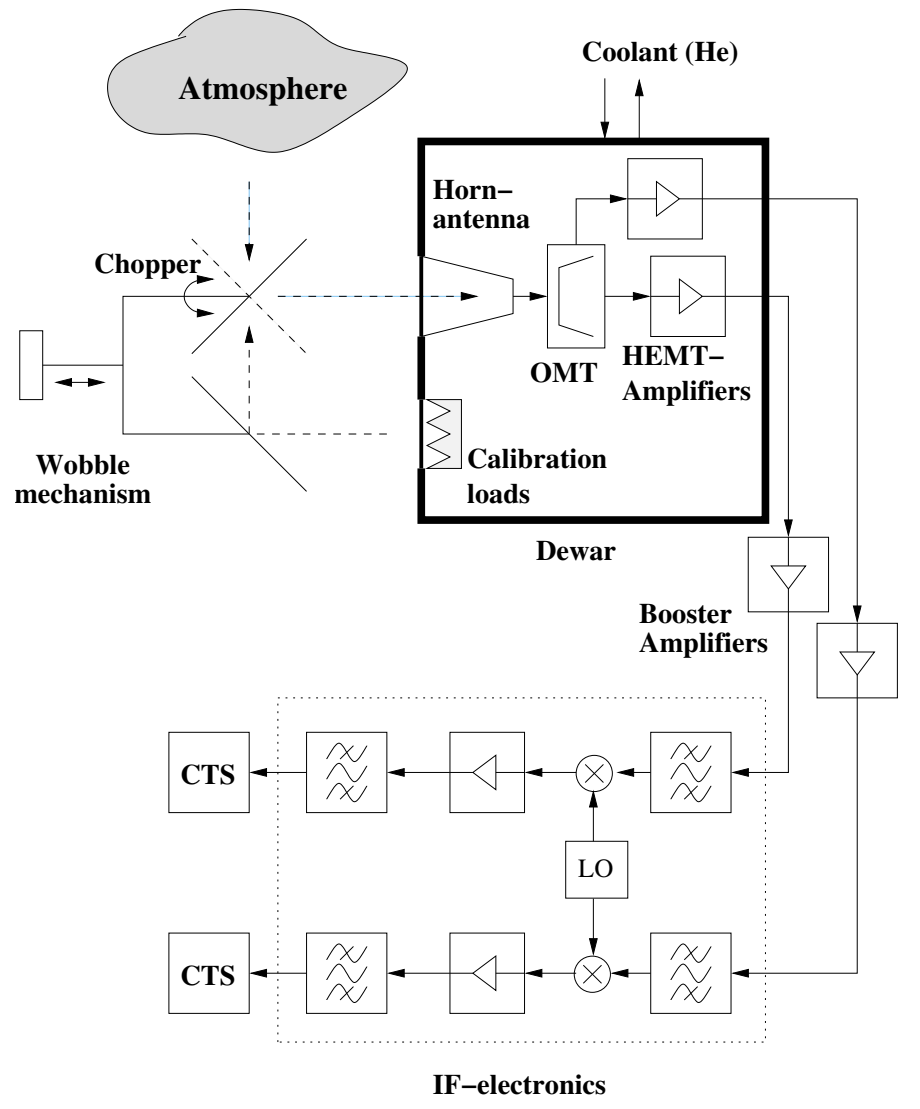

Fig. 1. A schematic overview of the instrument. The main mirror is rotated to switch the beam between the loads and the atmosphere. In the dewar the incoming signal is split into two identical signal chains (one for each polarisation) where it is amplified, down-converted and filtered before analysis in the CTSs.

\section{AMTD}

$6,4677-4703,2013$

A ground-based microwave spectrometer

K. Hallgren et al.

\section{Title Page}

Abstract

Introduction

Conclusions

References

Tables

Figures

14

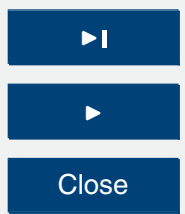

Back

Close

\section{Full Screen / Esc}

Printer-friendly Version

Interactive Discussion 


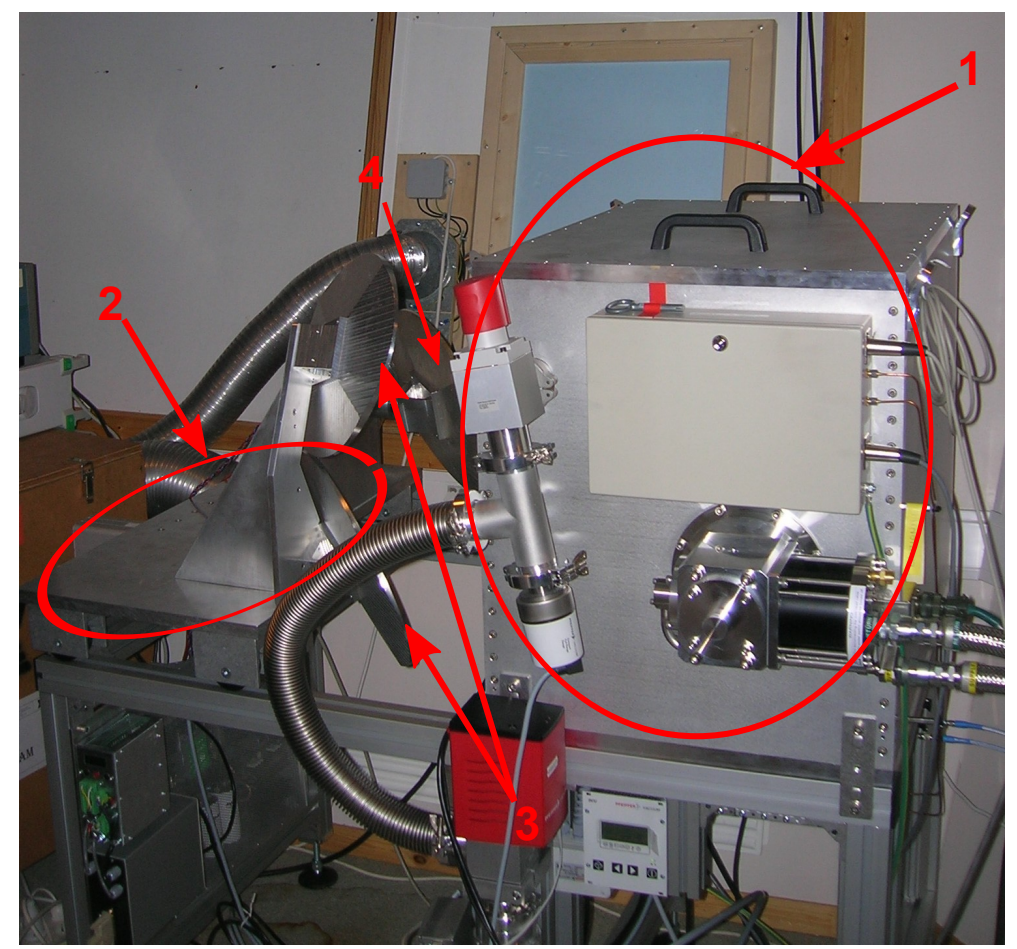

AMTD

6, 4677-4703, 2013

A ground-based microwave spectrometer

K. Hallgren et al.

\section{Title Page}

\section{Abstract}

Introduction

Conclusions

References

Tables

Figures

14

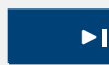

4

Back

$>$

\section{Full Screen / Esc}

Printer-friendly Version

Interactive Discussion

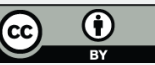




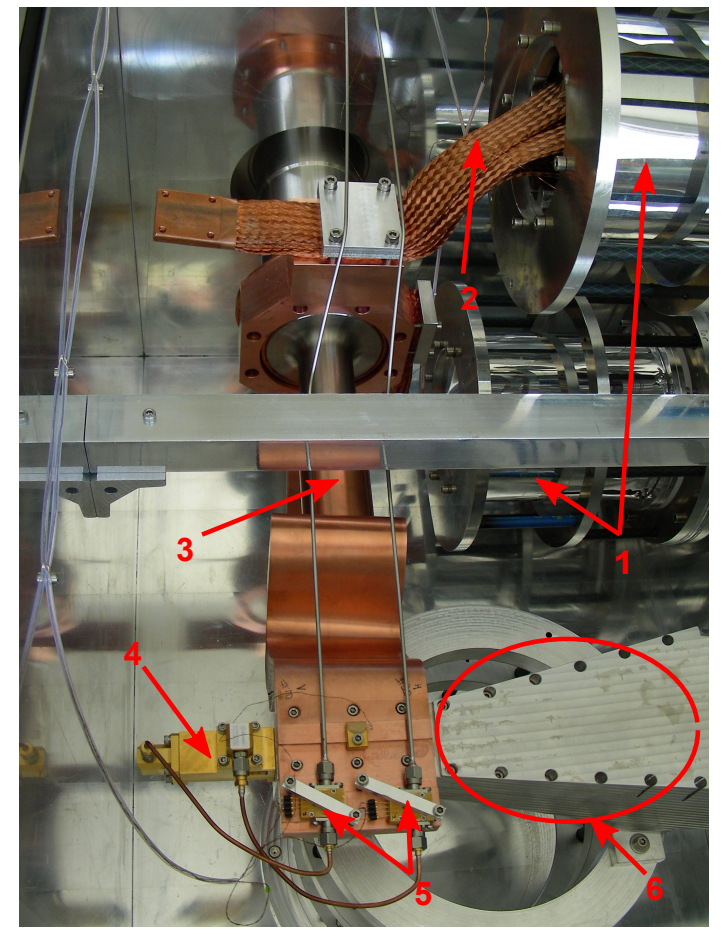

Fig. 3. The interior of cWASPAM1 with the calibration loads (1) and their connection (2) to the cold finger (3). The OMT (4), HEMT amplifiers (5) and horn antenna (6) are mounted directly on the cold finger.

\section{AMTD}

6, 4677-4703, 2013

A ground-based microwave spectrometer

K. Hallgren et al.

\section{Title Page}

Conclusions

References

Tables

Figures

14

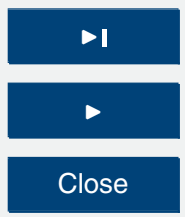

Back

Close

\section{Full Screen / Esc}

Printer-friendly Version

Interactive Discussion 

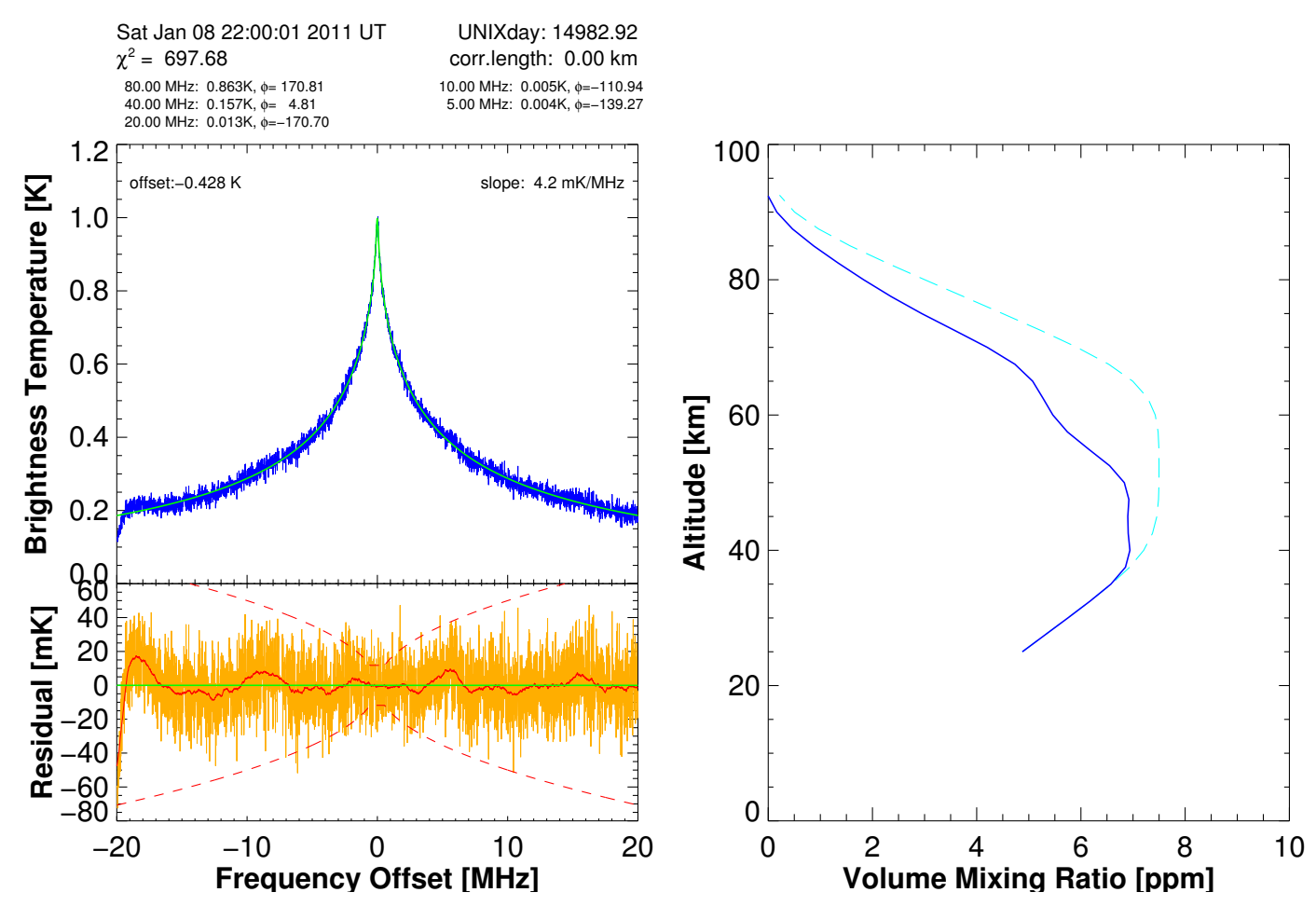

\section{AMTD}

$6,4677-4703,2013$

A ground-based microwave spectrometer

K. Hallgren et al.

\section{Title Page}

\section{Abstract}

Fig. 4. A typical spectral line after $4 \mathrm{~h}$ of integration with the corresponding vertical profile. In the upper left panel the actual measured line is marked in blue and the fit according to the forward model is overplotted in green. The lower left panel shows the residual and covariance of the observed line. To the right the vertical profile is shown in blue and the a priori can be seen in cyan.

\section{4}

4

Back

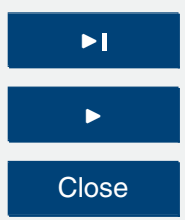

Full Screen / Esc

Printer-friendly Version

Interactive Discussion 


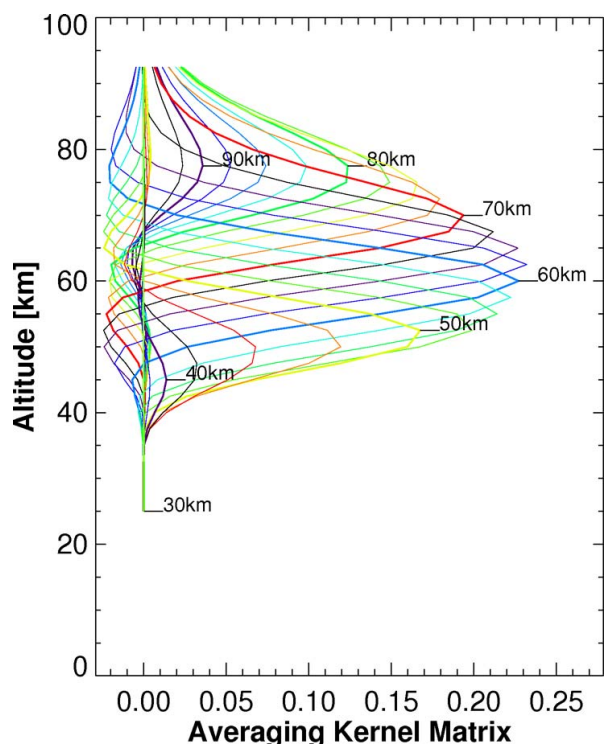

AMTD

$6,4677-4703,2013$

A ground-based microwave spectrometer

K. Hallgren et al.

\section{Title Page}

Abstract

Introduction

Conclusions

References

Tables

Figures

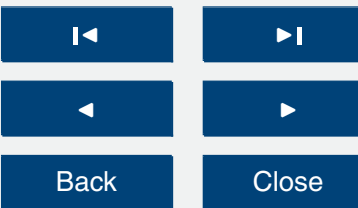

Fig. 5. Averaging kernels corresponding to the line in Fig. 4.

\section{Full Screen / Esc}

Printer-friendly Version

Interactive Discussion 


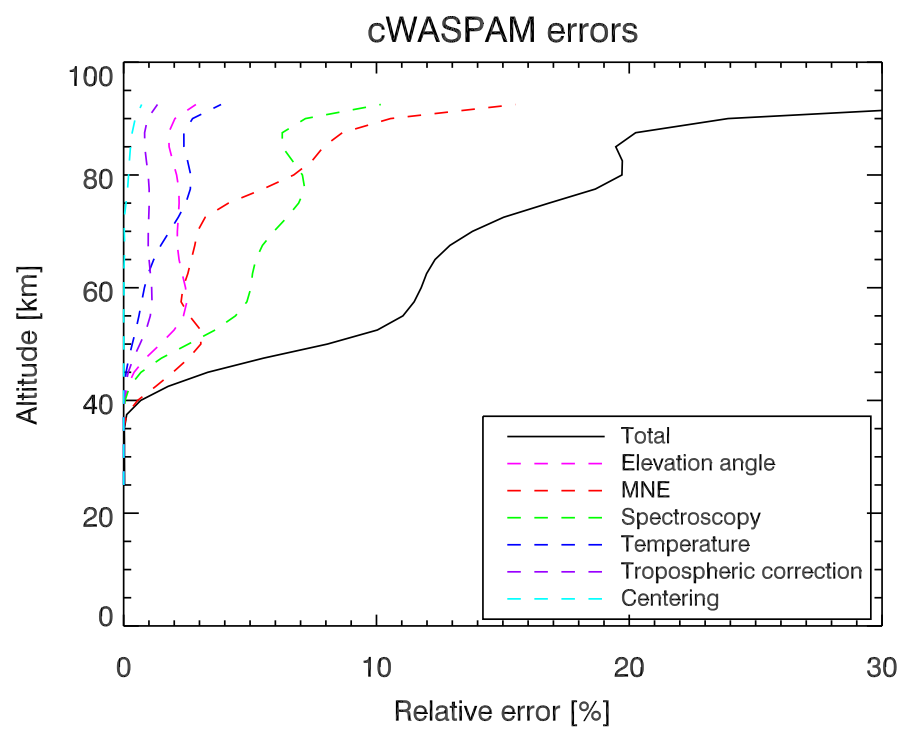

AMTD

6, 4677-4703, 2013

A ground-based microwave spectrometer

K. Hallgren et al.

\section{Title Page}

Abstract

Introduction

Conclusions

References

Tables

Figures

14

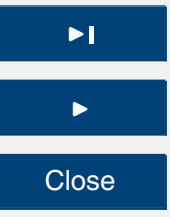

Back

Close

Full Screen / Esc

Printer-friendly Version

Interactive Discussion 


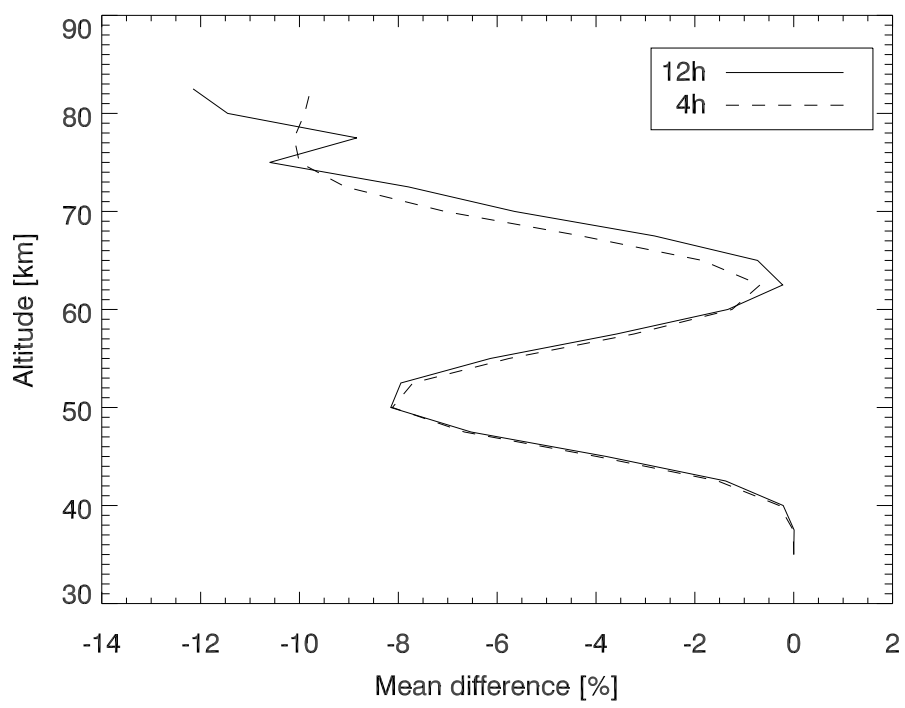

Fig. 7. Relative difference of water vapour profiles above Zugspitze from cWASPAM3 and EOSMLS. The solid line is based on a $12 \mathrm{~h}$ integration whereas the dashed is based on a $4 \mathrm{~h}$ integration. As can be seen the lines are almost identical and show a dry bias compared to EOS-MLS.

\section{AMTD}

$6,4677-4703,2013$

A ground-based microwave spectrometer

K. Hallgren et al.

\section{Title Page}

Abstract

Introduction

Conclusions

References

Tables

Figures

14

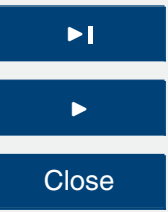

Back

Close

Full Screen / Esc

Printer-friendly Version

Interactive Discussion 